\title{
SUBSTITUTION OF QUARRY DUST TO SAND FOR MORTAR IN BRICK MASONRY WORKS
}

\author{
Appukutty P. ${ }^{1}$, Murugesan R. ${ }^{2}$ \\ ${ }^{1}$ P.A. Polytechnic College, Pollachi, India \\ ${ }^{2}$ Sri Ranganathar Engineering College, Coimbatore, India \\ Email: ${ }^{1}$ kuttygounder@yahoo.com
}

\begin{abstract}
Substitution of crusher dust for sand in cement mortar for brick masonry is experimented with brick masonry prisms cast in different ratios of 1:8, 1:6, 1:5 and 1:4. Bricks with basic compressive strength above $3.5 \mathrm{~N} / \mathrm{MM}^{2}$ and $7.5 \mathrm{~N} / \mathrm{MM}^{2}$ were used to cast brick masonry prisms. Three types of fine aggregates, i.e. Cauvery river sand, Crusher dust as is available form stone crushers and crusher dust in which fines below 150 microns removed were used for mortar. Three samples of brick masonry prisms in each mortar ratio were built, cured for 28 days and tested for the basic compressive strength. The results of 12 prisms tested in each fine aggregate with different mortar ratios are compared with allowable compressive strength requirements of brick masonry specified by IS 1905-1989. The investigation indicates that the crusher dust can replace natural sand completely in masonry construction with higher strength and cheaper cost.
\end{abstract}

Key words: Crusher Dust, Brick masonry prisms, Compressive strength

\section{INTRODUCTION}

With the increased shortage of natural river sand for construction due to over exploitation from sources and the inability of the nature to replace it and increasing pressures from local bodies, to protect the environment, either replacement or substitution for sand is warranted during this decade and for future.

The crusher dust, amounting to $25 \%$ of the coarse aggregates produced in stone crushers which were considered to be waste material facing the solid waste disposal problem, is being experimented as an alternate to river sand in construction industry for concrete and masonry works. Equal or excess quantity of sand is required for brick masonry and stone masonry in any construction project when compared to the concrete consumption in the same project

The fines below 150 microns in crusher dust will have high affinity to water which creates high water demand and reduced strength in masonry or concrete and hence as a trial, these fines below 150 microns were removed. The micro fines below 150 microns will be about $15 \%$ of the total volume of crusher dust. These micro fines can be removed by vacuum de dusting system with bag filters in the crusher itself.

Investigations on the strength of concrete with crusher dust as partial and full replacement of fine aggregates are reported by several researchers. Shau 'etal' and Shukla 'etal' investigated the use of crusher dust for partial replacement of sand. Prakash Rao's 'etal' investigations were with full replacement of sand with crusher dust in concrete only. Investigations on full replacement of sand for mortar in brick masonry with crusher dust as is available from the crusher are reported in this paper. Also, the fines below 150 micron size are removed from this unrefined crusher dust and the micro fines removed crusher dust is used for full replacement of sand in masonry and tested for basic compressive strength. So, the experimental work with micro fines removed crusher dust as 100\% replacement for sand in brick masonry work is not reported so far.

36 numbers of standard brick masonry prisms were constructed using bricks of strength not less than 3.5 $\mathrm{N} / \mathrm{mm}^{2}$ with cement mortar $1: 4,1: 5,1: 6$ and $1: 8,3$ numbers in each ratio, fine aggregate being river sand, unsieved crusher dust (URD) and 150 micron free crusher dust (FRD). Another set of 36 numbers prisms were cast using bricks of strength not less than $7 \mathrm{~N} / \mathrm{mm}^{2}$ and all the 72 masonry prisms were tested on the 28" day of casting.

\section{RESEARCH SIGNIFICANCE}

Crusher dust considered to be a solid waste material posing a serious disposal problem is utilized as full replacement material for sand in brick masonry works. Further, the micro fines below 150 micron size, presenting in the crusher dust are removed by sieving and micro fine free crusher dust is used as the alternative to sand. Three sets of experiments with mortar having fine aggregate as

i) sand

ii) unsieved dust

iii) micro fines removed dust in brick masonry has been undertaken 


\section{EXPERIMENTAL PROGRAMME}

The basic compressive strength of the brick masonry is established by conducting tests on brick masonry prisms built in accordance with IS 1905-1987. The specimen prisms are of size $230 \times 230 \times 920 \mathrm{~mm}$ with height to thickness ratio less than 5 .

\section{A. Material}

Two types of bricks confirming to IS 1077-1976 one with compressive strength not less than $3.5 \mathrm{~N} / \mathrm{mm}^{2}$ and another one with $7.5 \mathrm{~N} / \mathrm{mm}^{2}$ were used in the investigation.

The bricks were purchased from brick kilns situated in the outskirts of Coimbatore. The weight, water absorption and perfection in shape of bricks are tested before constructing brick prisms for investigation.

The size of bricks were $230 \times 115 \times 75 \mathrm{~mm}$. Average basic compressive strength of first set of bricks and IInd set of bricks were $4.0 \mathrm{~N} / \mathrm{mm}^{2}$ and $9.5 \mathrm{~N} / \mathrm{mm}^{2}$ respectively.

The cement used for the investigation was 53 grade Birla Cement. The initial and final setting times were respectively 68 minutes and 320 minutes. The compressive strength of mortar cubes of mix 1:3 at 28 days was $25.51 \mathrm{~N} / \mathrm{mm}^{2}$.

Fine aggregate used for mortar were (1) sand extracted from Cauvery river near Karur, Tamilnadu, without any refinement (2) Crusher dust procured from Pollachi $40 \mathrm{Kms}$ away from Coimbatore, Tamilnadu without any refinement or sieving (3) Crusher dust from the same stone crusher unit but refined by removing the micro fines below 150 microns size. Sieve analysis had been done for sand, unsieved crusher dust and fines removed crusher dust.

Sieve analysis on 3 type of fine aggregates indicates the grading and fineness modulus of the aggregate. The results are tabulated and grading curves are shown in fig. 1,2,3.

Zone-II SAND

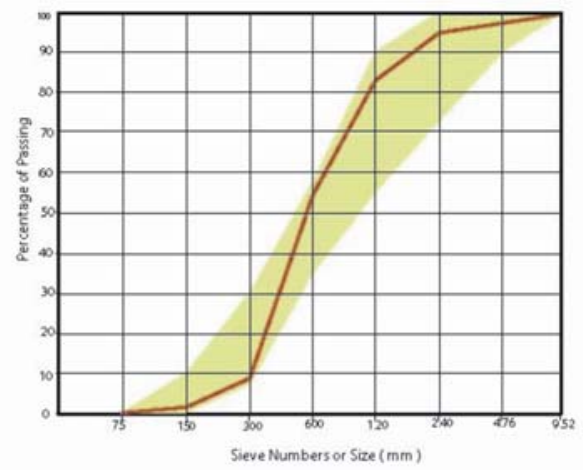

Fig. 1. Grading curve of Sand

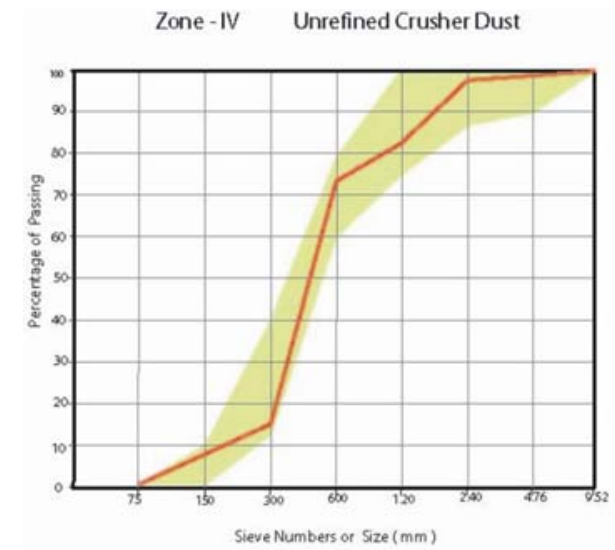

Fig. 2. Grading curve of Unrefined Crusher dust

Zone - III Fines Removed Crusher Dust

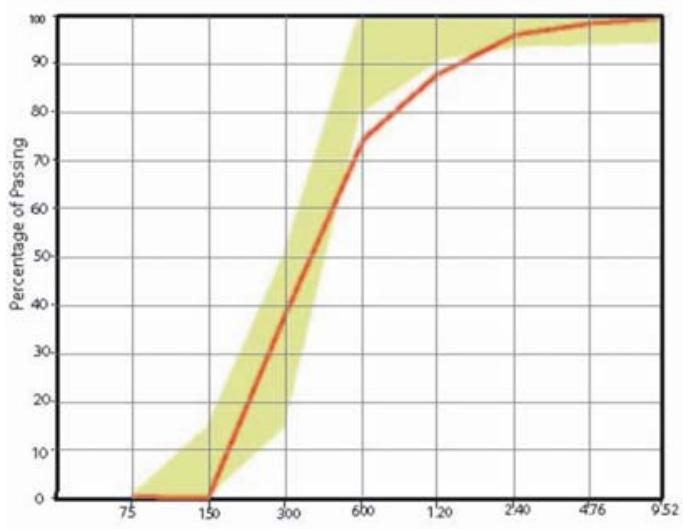

Fig. 3. Grading curve of Fines removed Crusher dust

Table 1. Percentage passing

\begin{tabular}{|l|l|l|l|l|}
\hline SI.No. & $\begin{array}{c}\text { Sieve } \\
\text { No. }\end{array}$ & \multicolumn{3}{|c|}{ \% of Passing } \\
\hline & & $\begin{array}{l}\text { Cauvery } \\
\text { River Sand }\end{array}$ & $\begin{array}{l}\text { Unrefined } \\
\text { Crusher Dust }\end{array}$ & $\begin{array}{l}\text { Fines } \\
\text { removed } \\
\text { Crusher } \\
\text { Dust }\end{array}$ \\
\hline 1. & 4.75 & 96.93 & 99.07 & 98.73 \\
\hline 2. & 2.36 & 94.60 & 97.82 & 97.02 \\
\hline 3. & 1.18 & 84.05 & 89.79 & 86.02 \\
\hline 4. & 0.6 & 66.87 & 80.84 & 73.75 \\
\hline 5. & 0.3 & 8.34 & 54.87 & 38.14 \\
\hline 6. & 0.15 & 1.00 & 27.05 & ---- \\
\hline 7. & 0.075 & 0.07 & 13.40 & ---- \\
\hline & & & & \\
\hline
\end{tabular}

Four basic mixes for mortar has been prepared in accordance with IS Code 2250-1981 and 1905-1987 provisions, the ratios being 1:4, 1:5, 1:6, 1:8 for building brick prisms for testing. 
One set of brick prisms designated as $A$, (Compressive strength greater than $3.5 \mathrm{~N} / \mathrm{mm}^{2}$ ) and the other set "B" (Compressive strength greater than 7 $\left.\mathrm{N} / \mathrm{mm}^{2}\right), 36$ prisms in each group.

\section{B. Preparation of specimens and Test}

The brick prisms of size $230 \times 230 \times 920 \mathrm{~mm}$ were cast in accordance with IS 1905-1987 specifications and cured for 28 days on platforms. A loading frame of 50 tones capacity with loading jack of 50 tones capacity were used to test the brick prisms. The prisms are placed between sheets of nominal $4 \mathrm{~mm}$ thick plywood, the upper platform of which is spherically seated.

The load was applied at the rate of 350 to $750 \mathrm{KN} / \mathrm{m}$ and distributed evenly over the whole top and bottom surfaces of the specimen. The loads at failure were recorded in figure 4 and 5 .

Basic compressive strength of the masonry is calculated as $1 / 4^{\prime \prime}$ of the basic compressive strength of brick masonry prism as per IS 1905 of 1989 and compared with allowable strength mentioned in Table of IS 1905-1989.

\section{RESULTS AND DISCUSSION}

The basic compressive strength of brick masonry (average of three prisms) is worked out and tabulated for group Aand group $B$.

* The Test results confirm that the performance of the crusher dust as fine aggregate in brickwork is better than the natural river sand.

* The refined crusher dust without micro fines below 150 micron contributes the maximum compressive strength when compared to sand and unrefined dust. (fig.6 and 7).

* In brick prisms using bricks of average compressive strength of $4 \mathrm{~N} / \mathrm{mm}^{2}$, first failure occurs in the bricks for CM 1:4, 1:5 and 1:6 and not in the mortar joints.

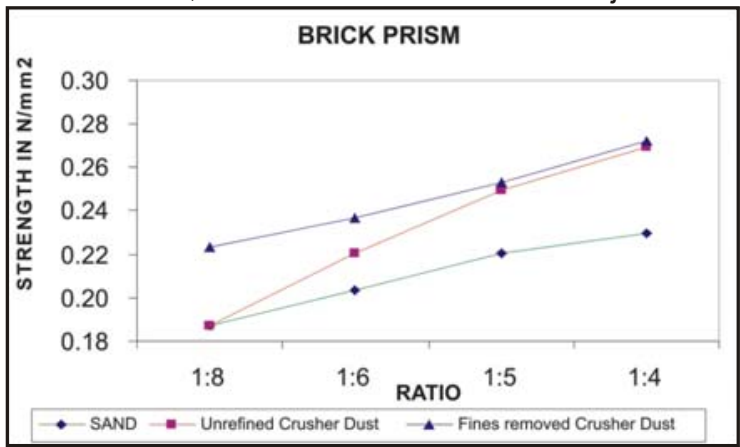

Fig. 4. Group A - Variation of compressive strength in brick masonry with alternate fine aggregate
* Mortar joints fail first in the case of brickwork using brick prisms with bricks of average strength not less than $7.5 \mathrm{~N} / \mathrm{mm}^{2}$.

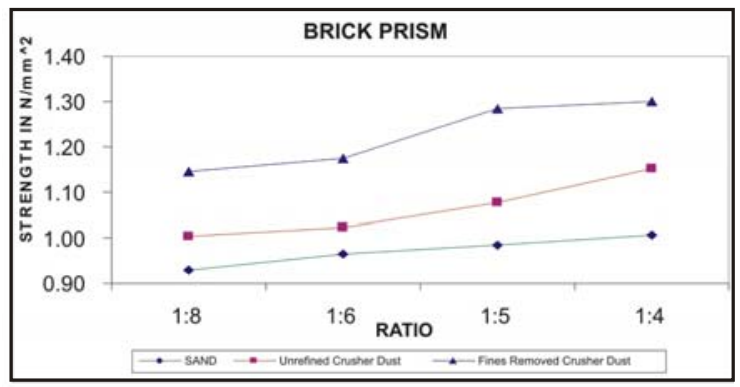

Fig. 5. Group B - Variation of compressive strength in brick masonry with alternate fine aggregate in mortar

Table 2. Comparison of compressive strength with group "B" Bricks

\begin{tabular}{|l|l|l|l|l|}
\hline & \multicolumn{4}{|l|}{$\begin{array}{l}\text { Basic Compressive Strength Of } \\
\text { Brick Masonry N/Mm2 }\end{array}$} \\
\hline $\begin{array}{l}\text { Fine Aggregate } \\
\text { mortar ratio }\end{array}$ & $1: 8$ & $1: 6$ & $1: 5$ & $1: 4$ \\
\hline SAND & 0.19 & 0.20 & 0.22 & 0.23 \\
\hline DUST & 0.19 & 0.22 & 0.25 & 0.27 \\
\hline SIEVED DUST & 0.22 & 0.24 & 0.25 & 0.27 \\
\hline $\begin{array}{l}\text { Allow stress as } \\
\text { per IS 1905- } \\
\text { 1989 }\end{array}$ & 0.19 & 0.26 & 0.26 & 0.26 \\
\hline
\end{tabular}

Table 3. Comparison of compressive strength with group "A" Bricks

\begin{tabular}{|l|l|l|l|l|}
\hline & \multicolumn{4}{|l|}{$\begin{array}{l}\text { Basic compressive strength of brick } \\
\text { masonry N/mm² }\end{array}$} \\
\hline $\begin{array}{l}\text { Fine } \\
\text { Aggregate } \\
\text { mortar ratio }\end{array}$ & $1: 8$ & $1: 6$ & $1: 5$ & $1: 4$ \\
\hline SAND & 0.93 & 0.96 & 0.99 & 1.01 \\
\hline DUST & 1.00 & 1.02 & 1.08 & 1.15 \\
\hline $\begin{array}{l}\text { SIEVED } \\
\text { DUST }\end{array}$ & 1.15 & 1.17 & 1.28 & 1.30 \\
\hline $\begin{array}{l}\text { Allow stress } \\
\text { as per IS } \\
\text { 1905-1989 }\end{array}$ & 0.47 & 0.56 & 0.67 & 0.67 \\
\hline
\end{tabular}

\section{COST ANALYSIS}

The cost of Brick masonry and Random rubble masonry in cement mortar 1:6 has been analysed with the average rates of materials in Coimbatore district in 
Table 4. Brick Masonry

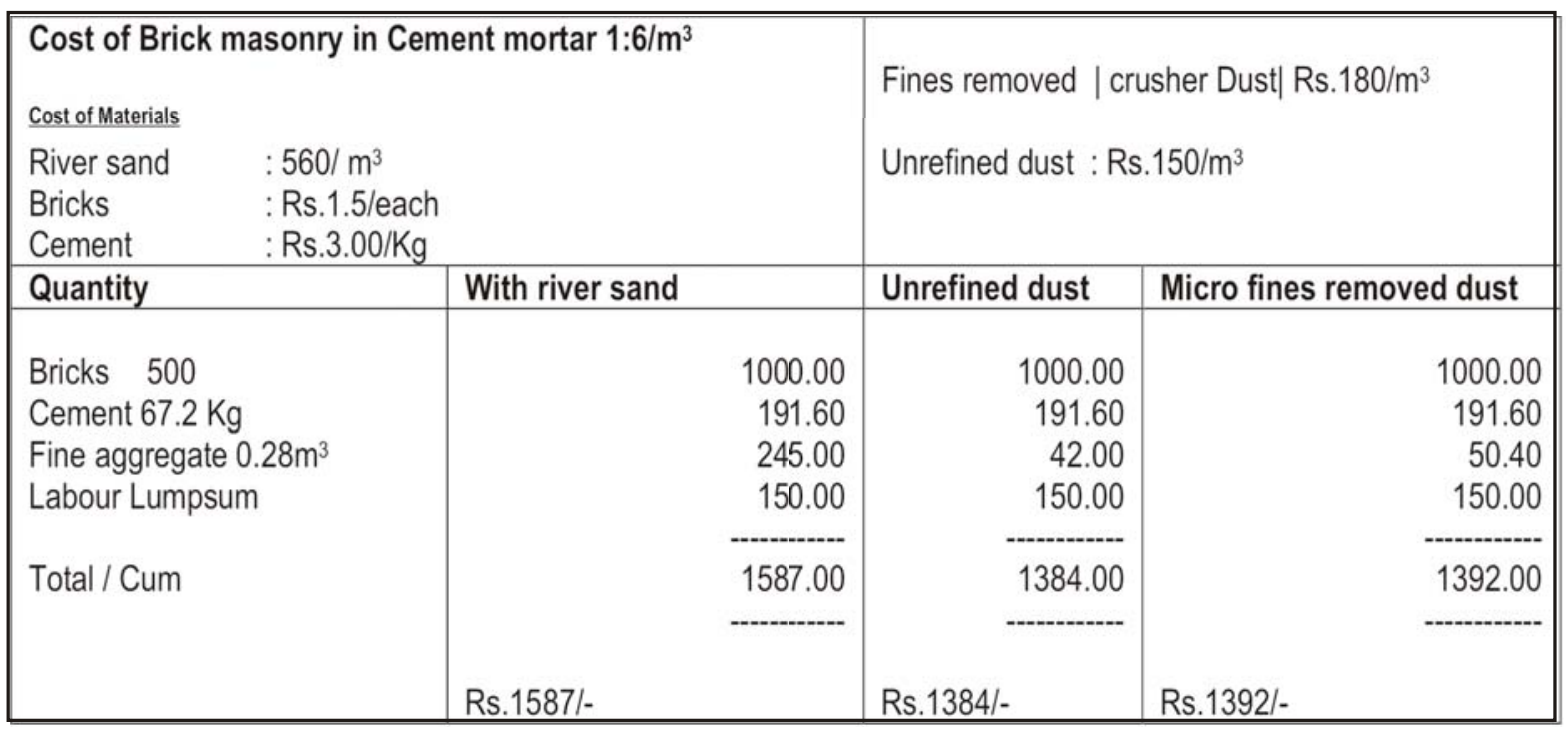

Tamilnadu and with three different fine aggregate used in this investigation.

The table 4 indicates savings of $13.0 \%$ fines removed dust and $12.5 \%$ with unrefined crusher dust. The comparative statement shows that about $12.75 \%$ of cost saving can be achieved in brickwork by replacing The table 5 shows that the replacement of sand by unrefined crusher dust and fines removed crusher dust will have savings of $21.70 \%$ and $20.80 \%$ respectively. and with crusher dust.

In accordance with IS 1905-1987 Table-8,note-4, the compressive strength of random rubble masonry is taken as 75 percent of the corresponding stress for

Table 5. Rubble Masonry

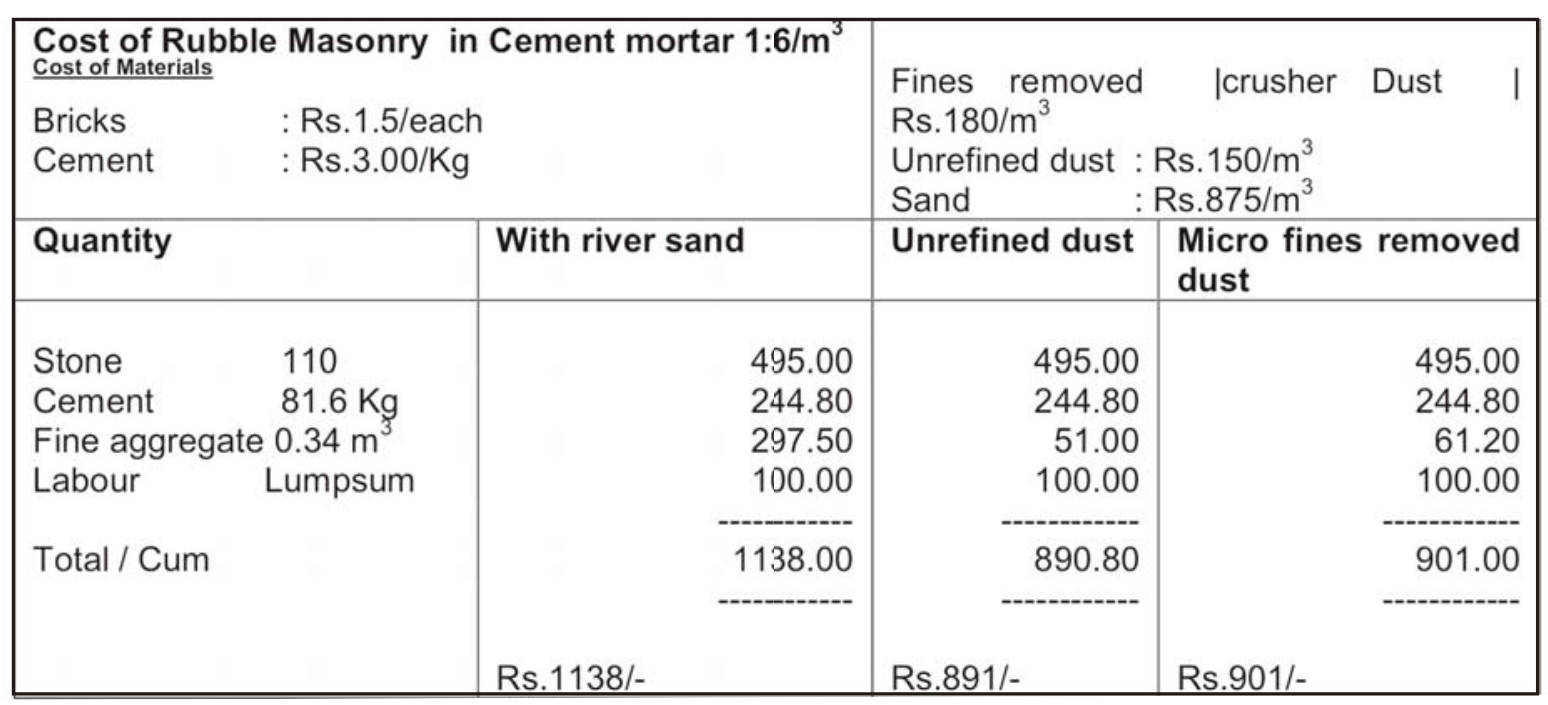


coursed walling of similar materials, the cost of analysis was made and compared.

\section{CONCLUSION}

The performance of the fines removed crusher dust in cement mortar for brickwork is better than sand and crusher dust in strength. There is cost reduction of abou $12.50 \%$ in brick work and $20.80 \%$ in stone masonry by replacing the sand

The utilization of crusher dust leads to eco friendly construction and economic construction.

\section{REFERENCES}

[1] Prakash Rao D.S., V. Giridharkumar., Investigations on concrete with stone crusher dust as fine aggregate, The Indian Concrete Journal, July 2004, pp 45-50.

[2] Misra V.N., Use of stone dust from crushers in cement-sand mortars, The Indian Concrete Journal, August 1984, Vol 58, No.8, pp 219-223.

[3] Babu, K.K.Radhakrishnan, R and Nambiar E.K.K. Compressive strength of brick masonry with alternative aggregate mortar, Civil Engineering and Construction Review, September 1997, Vol 10, No.9, pp 25-29.

[4] Sahu, A.K., Kumar, Sunil and Sachan, A.K. crushed stone waste as fine aggregate for concrete, The Indian Concrete Journal, January 2003, Vol 77, No.1, pp 845-847.
[5] Recommended guidelines under IS383-1963 Specification for coarse and fine aggregates from Natural sources for concrete (Revised)

[6] Recommended guidelines under 1077-1970 Specification for common burnt clay building bricks (Second revision)

[7] Recommended guidelines under 1905-1987 - Code of procedure for structural use of un-reinforced masonry.

[8] Recommended guidelines under IS2250-1981 Code of practice for preparation and use of masonry mortars (First revision).

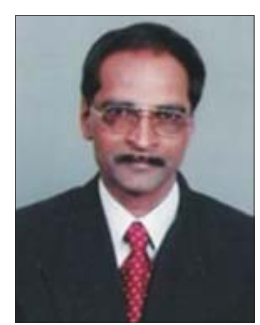

Prof. P. Appukutty is the Chairman of P.A. College of Engineering and Technology and P.A. Polytechnic College, Pollachi, India. He has provided Consultancy services in the area of Construction of Temples, Industries and Educational Institutions. He has three years of experience in Military Engineer services and over thirty six years of teaching experience 